\title{
ISOLASI BAKTERI YANG BERSIMBION DENGAN ASCIDIAN Herdmania momus YANG MEMILIKI AKTIVITAS ANTIBAKTERI
}

\author{
(Isolation of Ascidian Herdmania momus Symbiotic Bacteria with Antibacterial Activity)
}

\author{
Silvia E. Koyongian ${ }^{1 *}$, Deiske A. Sumilat ${ }^{1}$, Rosita A. J. Lintang ${ }^{1}$, Stenly Wullur ${ }^{1}$, \\ Sandra O. Tilaar ${ }^{1}$, Henneke Pangkey ${ }^{2}$
}

${ }^{1}$ Program Studi IImu Kelautan, FPIK UNSRAT Manado

2Jurusan Manajemen Sumber Daya Perairan, FPIK UNSRAT Manado

*email: koyongiansilvia9@gmail.com

\begin{abstract}
Ascidian are marine invertebrates in coral reef ecosystems that produces many bioactive compounds for pharmacology. The presence of symbiotic bacteria with marine organisms is protect the host biota by producing secondary metabolites. The purpose of this study is to obtain symbiotic bacterial isolates with Herdmania momus ascidian, then to observe the antibacterial activity of these bacterial isolates against Escherichia coli, and Staphylococcus aureus. Isolation and culture of the symbiotic bacteria were made on Nutrient Agar and Zobell Marine Broth media. The antibacterial screening showed that the Herdmania momus symbiotic bacteria were able to inhibit the growth of Staphylococcus aureus and Escherichia coli.
\end{abstract}

Keywords: ascidians, Herdmania momus, bacteria, isolation, antibacterial

Ascidian adalah avetebrata laut di ekosistem terumbu karang yang banyak menghasilkan senyawa bioaktif untuk bidang farmakologi. Keberadaan bakteri yang bersimbion dengan organisme laut pada umumnya untuk melindungi biota yang ditumpanginya dan dirinya dengan cara menghasilkan senyawa metabolit sekunder. Tujuan dari penelitian ini yaitu untuk mendapatkan isolat bakteri yang bersimbion dengan ascidian Herdmania momus, kemudian mengamati aktivitas antibakteri dari isolat bakteri tersebut terhadap Escherichia coli, dan Staphylococcus aureus. Isolasi dan kultur bakteri yang bersimbion dengan ascidian dibuat pada media Nutrient Agar dan Zobell Marine Broth. Skrining aktivitas antibakteri menunjukkan isolat bakteri yang bersimbion dengan ascidian Herdmania momus mampu menghambat pertumbuhan organisme uji Staphylococcus aureus dan Escherichia coli.

Kata kunci: ascidian, Herdmania momus, bakteri, isolasi, antibakteri

\section{PENDAHULUAN}

Ascidian merupakan avertebrata di ekosistem terumbu karang yang banyak menghasilkan senyawa bioaktif untuk bidang farmakologi. Dimana hewan ini dapat berasosiasi dengan mikroba fotosintetik dan mempunyai potensi molekular yang besar, karena kandungan metabolit sekundernya yang merupakan substansi bioaktif (Karim et al., 2018) Senyawa bioaktif yang disintesis oleh ascidian merupakan metabolit sekunder, yaitu metabolit turunan secara biosintetik dari metabolit primer yang digunakan dalam sistem pertahanan diri, yaitu untuk mempertahankan hidup dan menghindari gangguan dari organisme lain di lingkungan tempat hidupnya. Karena aktivitas farmakologinya maka senyawa tersebut memiliki prospek untuk diisolasi dan dimanfaatkan dalam bidang farmasi (Sumilat et al., 2018).

Penelitian terhadap ascidian telah berkembang dengan baik, yang mengarah pada isolasi berbagai metabolit yang memiliki struktur yang unik dan senyawa bioaktivitas yang besar. Hal ini membuat ascidian memiliki potensi sebagai sumber obat-obatan baru untuk mengobati berbagai penyakit; produk yang dihasilkan seperti larvasida (Rumengan, 2010; Mangindaan dan Taroreh, 2013) antitumor, antikanker (Tatsuta et al., 2017; Sumilat et al., 2017; Watters, 2018) antibakteri (Liu et al., 2004; Opa dkk., 2018; Sumilat et al., 2019), antioksidan (Sumilat et al., 2019) dan antijamur (Karim et al., 2018).

\begin{abstract}
Ascdian Herdmania momus merupakan ascidian soliter atau hidup menyendiri. Secara morfologi ascidian $H$. momus berbentuk bundar dengan sifon berbentuk terompet. Pinggiran oral sifonnya sangan mencolok, berwarna cokelat, berbintikbintik merah dan putih kebiruan. Beberapa peneliti menempatkan spesies ini kedalam genus Pyura (Gosliner et al., 1996). Acscidian $H$. momus diketahui memiliki aktivitas antibakteri dan antioksidan (Sumilat et al.,2019).
\end{abstract}

Senyawa bioaktif yang diekstrak secara besar-besaran dari organisme laut akan merusak keberadaan organisme itu sendiri dan bertentangan dengan kepentingan konservasi (Pastra dkk., 2012). Oleh sebab itu, eksplorasi bakteri simbion dari ascidian perlu dilakukan untuk mengetahui apakah bakteri yang bersimbion dengan ascidian mampu menghasilkan senyawa antibakteri yang dapat bermanfaat dalam bidang farmasi.

Tujuan dari penelitian ini yaitu untuk mendapatkan isolat bakteri yang bersimbion dengan ascidian Herdmania momus, dan melakukan skrining aktivitas antibakteri dari isolat bakteri tersebut terhadap Escherichia coli, dan Staphylococcus aureus. 


\section{METODE PENELITIAN}

Pada penelitian ini sambel dikoleksi dari Perairan Pangalisang Bunaken, Kecamatan Bunaken, Manado, Sulawesi
Utara. Lokasi pengambilan di daerah intertidal ke subtidal pada celah-celah terumbu karang. Untuk lokasi pengambilan sampel dapat dilihat pada Gambar 1.

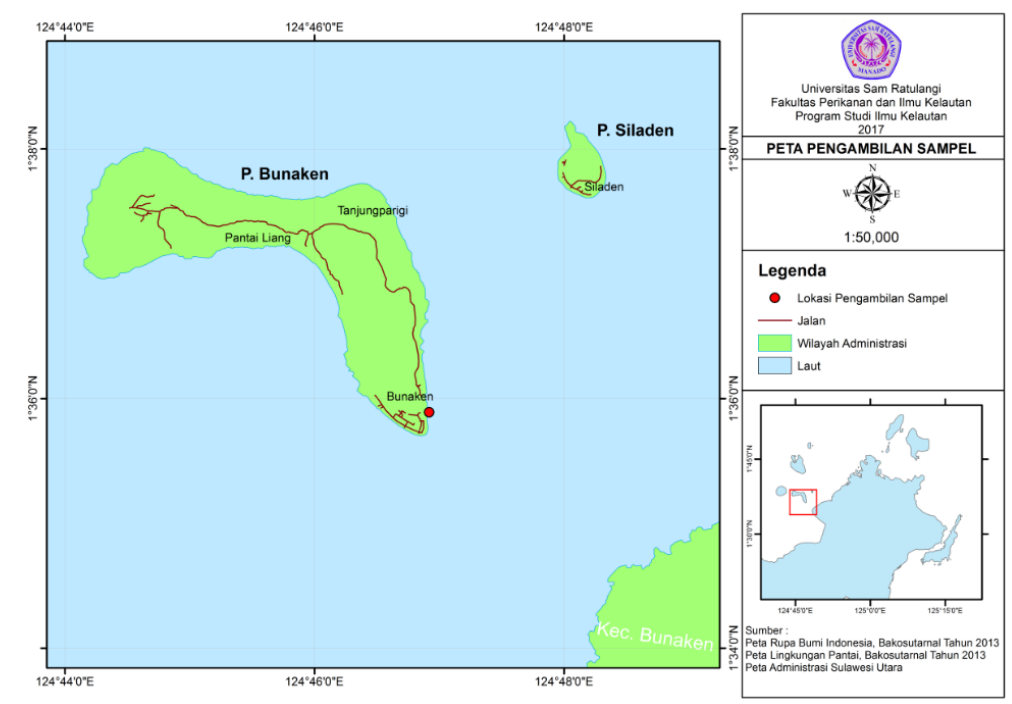

Gambar 1. Peta lokasi pengambilan sampel.

\section{Pengambilan dan Identifikasi Sampel}

Sampel ascidian diperoleh dari perairan Pangalisang Bunaken dengan cara menyelam (skin dive) dengan menggunakan 1 set alat snorkeling pada kedalaman $\pm 3-7$ meter. Pengambilan sampel acidian dilakukan dengan cara memotong organisme ascidian langsung dari substratnya. Kemudian sampel yang telah dimasukkan ke dalam plastik sampel bersih. Sampel selanjutnya dibawa ke Laboratorium Biologi Molekuler dan Farmasetika Laut Fakultas Perikanan dan IImu Kelautan UNSRAT untuk penelitian lebih lanjut.

Identifikasi sampel dilakukan dengan cara mengamati secara morfologi yaitu bentuk, warna, dan tekstur dari ascidian. Identifikasi spesies dipandu menggunakan buku "Coral Reef Animals of the Indo-Pasific" (Gosliner et al., 1996).

\section{Sterilisasi Alat dan Bahan}

Alat-alat yang digunakan dalam penelitian ini seperti cawan petri, tabung reaksi, pisau, erlenmyer dan pinset dicuci bersih, dikeringkan, dibungkus kemudian disterilkan dalam oven pada suhu $150^{\circ} \mathrm{C}$ selama \pm 2 jam (sterilisasi kering). Media untuk pertumbuhan mikroorganisme disterilisasi dalam autoklaf pada suhu $121^{\circ} \mathrm{C}$ selama 15 menit (sterilisasi basah).

\section{Pembuatan Media NA (Nutrient agar)}

Pembuatan media NA menggunakan bahan 2 gram NA, 0,5 gram agar, air laut dan akuades. Bahan yang sudah ditimbang dimasukkan ke dalam erlenmyer yang sudah berisi air laut saring 50\% sebanyak $100 \mathrm{ml}$. Media dibuat sebanyak 1 erlenmyer dan disterilkan menggunakan autoklaf pada suhu $121^{\circ} \mathrm{C}$ selama \pm 15 menit. Media NA dibuat untuk isolasi bakteri pertama kali. $\begin{aligned} & \text { Pembuatan Media ZMB (Zobell Marine } \\ & \text { Broth) }\end{aligned}$
(2)

Media ZMB dibuat dengan melarutkan 4.025 gram ZMB bersama 2 gram agar dalam wadah erlenmeyer berisi $100 \mathrm{ml}$ akuades, selanjutnya disterilkan menggunakan otoklaf pada suhu $121^{\circ} \mathrm{C}$ selama \pm 15 menit.

\section{Isolasi Bakteri Simbion Ascidian}

Proses isolasi, kultur, dan pemurnian bakteri dilakukan berdasarkan panduan buku "Microbiology Laboratory Manual" (Varghese and Joy, 2014). Ascidian dipotong kecil-kecil dan dicelupkan selama 60 detik kedalam etanol $70 \%$ kemudian ditanam pada media NA dan diinkubasi selama 2×24 jam.

\section{Kultur Bakteri Simbion Ascidian (Pemurnian)}

Pemurnian kultur isolat bakteri dimaksudkan untuk mendapatkan koloni terpisah yang merupakan biakan murni. Metode yang digunakan adalah metode gores (streak plate method). Metode ini dilakukan dengan menggoreskan 1 ose bakteri pada permukaan media padat ZMB dalam cawan petri dengan pola goresan kuadran.

\section{Pembuatan Media B1 dan Preparasi Bakteri Uji}

Pembuatan Media B1: Media B1 dibuat menggunakan bahan Pepton 0,5 gram, ekstrak daging (meat extract) 0,3 gram, Natrium Klorida ( $\mathrm{NaCl}$ ) 0,3 gram dilarutkan dalam 100 $\mathrm{ml}$ akuades. disterilkan menggunakan autoklaf pada suhu $121^{\circ} \mathrm{C}$ selama \pm 15 menit.

Media padat B1 dibuat dengan cara yang sama, hanya menambahkan Agar dengan konsentrasi $2 \%$.

\section{Preparasi Bakteri Uji}


Kultur bakteri uji $S$. aureus dan E. coli dibuat dengan menumbuhkan kedua bakteri tersebut dalam media yang telah dipersiapkan sebelumnya. Sebanyak 1 ose bakteri ditumbuhkan dalam media cair 1x24 jam dan ditambahkan dalam media padat untuk proses pengujian selanjutnya.

\section{Skrining Antibakteri dari Bakteri Simbion Ascidian}

Skrining antibakteri dilakukan terhadap isolat murni yang diperoleh untuk mengetahui isolat mana yang memiliki aktivitas antibakteri. Bakteri uji yang digunakan adalah $S$. aureus dan $E$. coli yang telah dicampurkan ke dalam edia B1 padat yang telah disiapkan sebelumnya. Isolat murni ditotolkan pada permukaan media B1 padat yang telah mengandung bakteri uji dan diinkubasi selama 1x24 jam kemudian lakukan pengamatan. Adanya zona hambat (inhibitory zone/clear zone) merupakan tanda adanya kepekaan terhadap bakteri uji.

\section{HASIL DAN PEMBAHASAN}

\section{Identifikasi Organisme Ascidian}

Sampel ascidian yang diperoleh saat sampling kemudian diidentifikasi dengan mengamati morfologinya dengan dibantu buku "Coral Reef Animals of the Indo-Pasific" (1996). Diketahui bahwa ascidian tersebut merupakan spesies Herdmania momus. Ciriciri ascidian $H$. momus adalah berbentuk globular (bundar), berwarna cokelat, dengan bintik-bintik merah kebiruan. Sifon dari ascidian $H$. momus sangat mencolok keluar (Gosliner et al., 1996) seperti pada Gambar 2. Ciri-ciri tersebut sesuai dengan sampel ascidian yang diperoleh dari perairan Pangalisang, Bunaken.

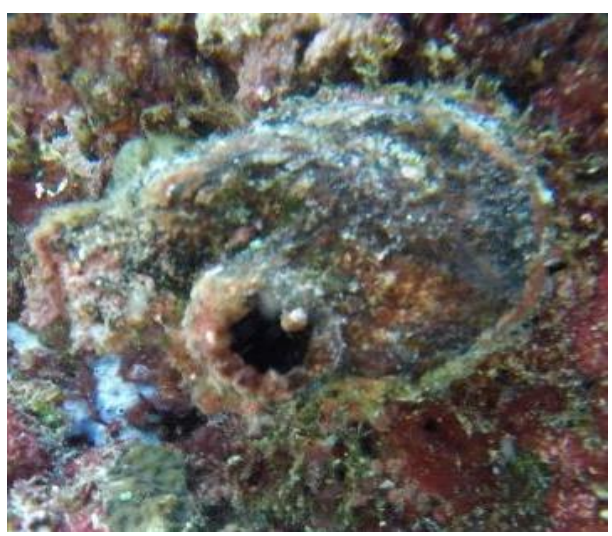

Gambar 2. Sampel ascidian Herdmania momus

\section{Isolasi Bakteri Ascidian}

Sampel yang telah diperoleh kemudian dibawa ke Laboratorium Biologi Molekuler dan Farmasetika Laut, FPIK, UNSRAT dan diisolasi. Gambar 3 memperlihatkan adanya pertumbuhan bakteri pada sekitar potongan sampel ascidian Herdmania momus setelah diinkubasi selama $2 \times 24$ jam yang ditandai dengan munculnya gumpalan berwarna putih susu.

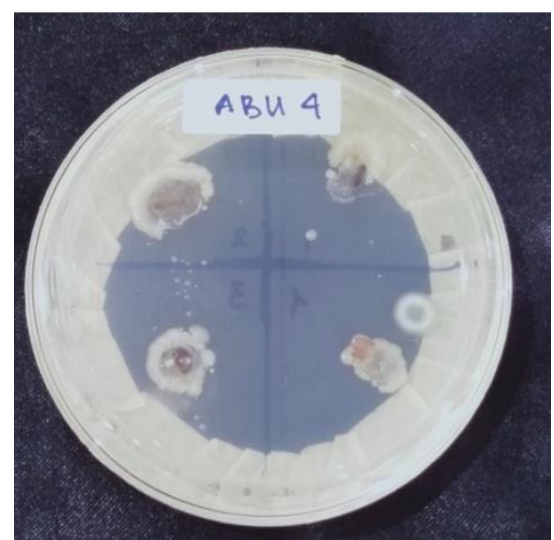

Gambar 3. Isolasi bakteri ascidian Herdmania momus

Bakteri yang tumbuh tersebut kemudian langsung dikultur kuadran untuk mendapatkan koloni tunggal dan diberikan kode pada setiap cawan petri. Hasil kultur setelah inkubasi selama 1×24 ditampilkan pada Gambar 4 sedangkan jumlah koloni terpisah disajikan dalam Tabel 1 

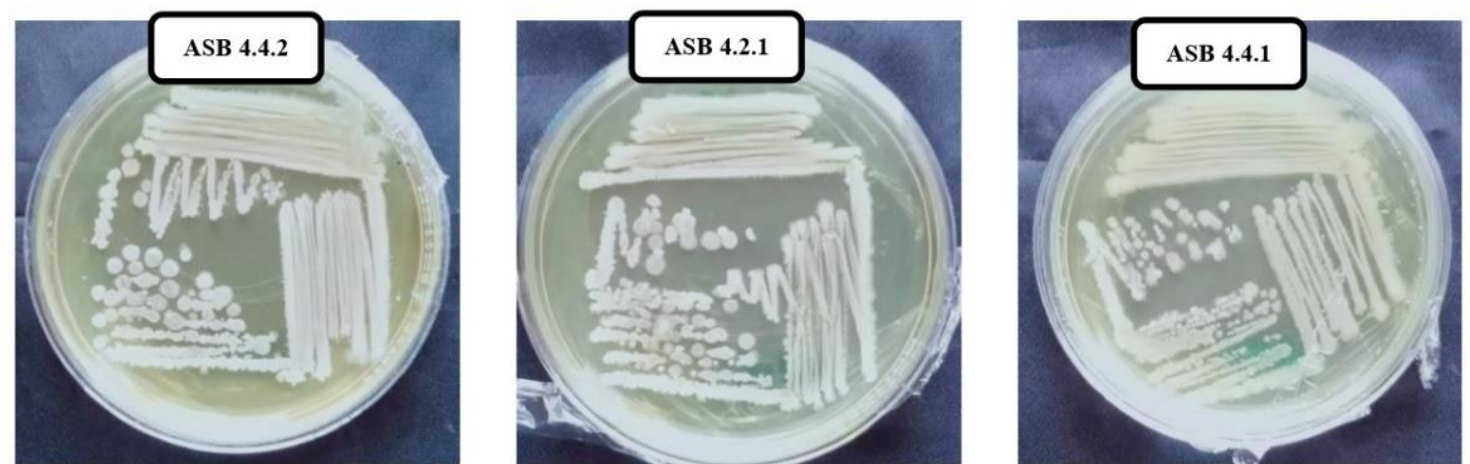

Gambar 4. Kultur bakteri ascidian Herdmania momus

Keterangan kode sampel:

- ASB: ascidian bunaken

- $\quad$ ASB 4.4.2: ascidian bunaken 4, strain keempat dan pemurnian kedua

- ASB 4.2.1: acidian bunaken 4, strain kedua dan pemurnian pertama

- $\quad$ ASB 4.4.1: ascidian bunaken 4, strain keempat dan pemurnian pertama

Tabel 1. Jumlah koloni tunggal bakteri simbion ascidian Herdmania momus No. Kode / Isolat Jumlah Koloni

\begin{tabular}{ccc} 
& & Tunggal \\
\hline 1. & ASB 4.4.2 & 18 \\
\hline 2. & ASB 4.2.1 & 23 \\
\hline 3. & ASB 4.4.1 & 21 \\
\hline
\end{tabular}

\section{Pemurnian Bakteri}

Hasil pengamatan morfologi isolat murni berdasarkan warna, bentuk dan karakteristik lain berdasarkan Varghese and Joy, 2014 dapat dilihat pada Gambar 5

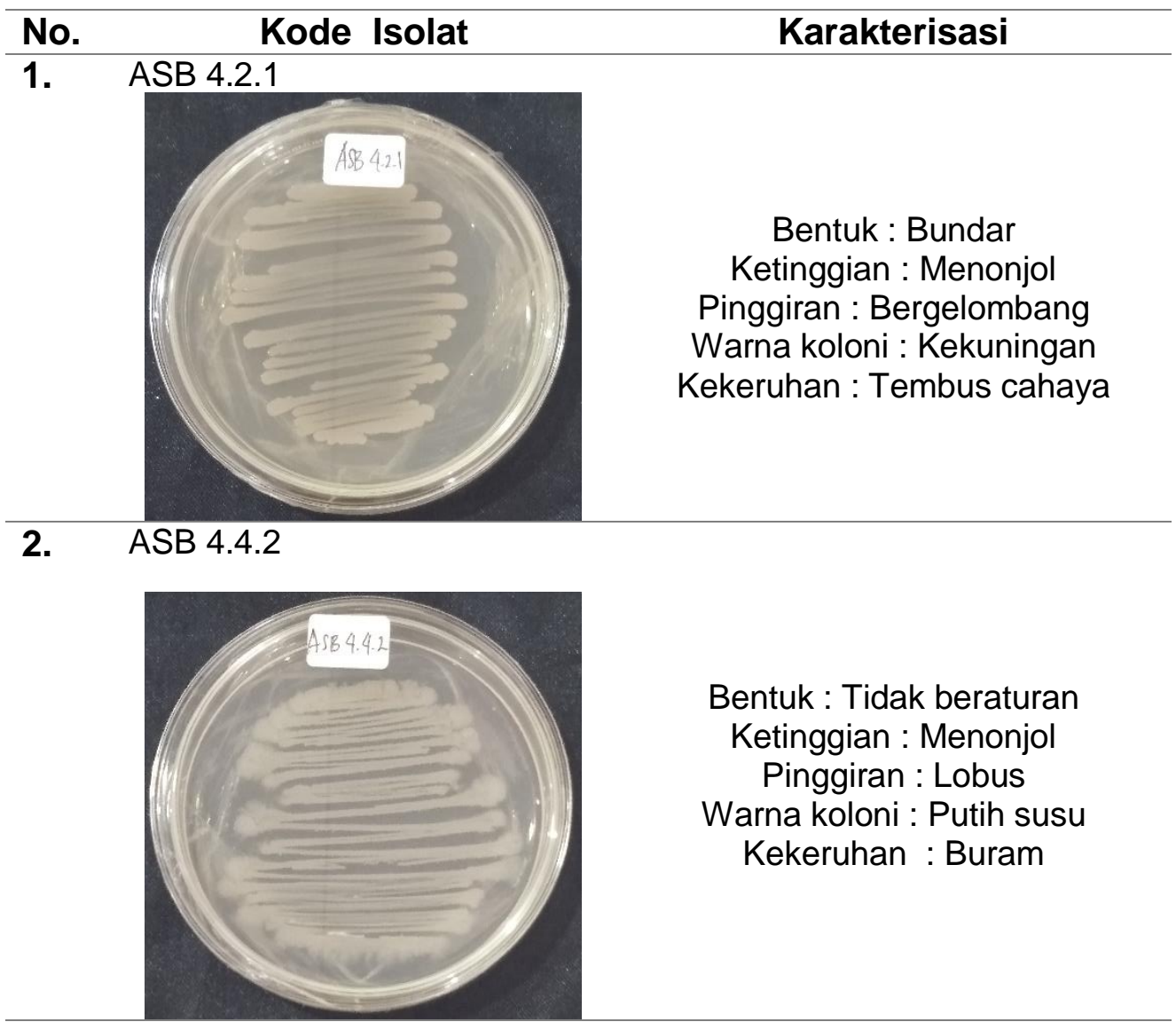


3. $\quad$ ASB 4.4.1

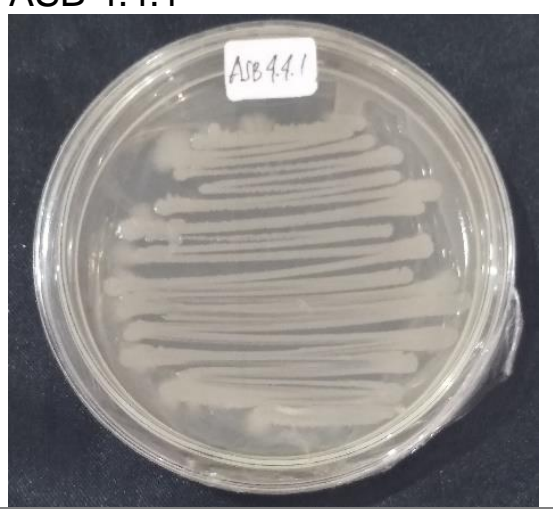

Bentuk : Tidak beraturan

Ketinggian : Menonjol

Pinggiran : Lobus

Warna koloni : Putih susu

Kekeruhan : Buram

Gambar 5. Karakteristik isolat murni bakteri simbion Ascidian Herdmania momus

\section{Skrining Aktivitas Antibakteri dari Bakteri Simbion Ascidian}

Tabel 3 merupakan hasil skrining aktivitas antibakteri dari isolat murni bakteri simbion ascidian Herdmania momus terhadap bakteri uji $S$. aureus dan E. coli. Skrining aktivitas antibakteri bertujuan untuk melihat isolat yang berpotensi dalam menghasilkan senyawa-senyawa yang mampu menghambat pertumbuhan bakteri pathogen.
Aktivitas antibakteri dilihat dengan adanya zona hambat atau clear zone/inhibitory zone pada sekitar isolat yang ditanam pada bakteri uji. Pengamatan hasil skrining aktivitas antibakteri dilakukan 2x24jam untuk mengetahui efek antimikroba yang terjadi pada masing-masing isolat bakteri.

Tabel 3. Aktivitas antibakteri dari isolat murni bakteri simbion ascidian Herdmania momus terhadap bakteri uji

\begin{tabular}{ccc}
\hline Kode Isolat & \multicolumn{2}{c}{ Bakteri Uji } \\
\cline { 2 - 3 } & S. aureus & E. coli \\
\hline 1 / ASB 4.4.2 & + & + \\
\hline 2 / ASB 4.2.1 & - & - \\
\hline 3 / ASB 4.4.1 & + & + \\
\hline
\end{tabular}

Hasil pengamatan $1 \times 24$ pada isolat 1/ASB 4.4.2 dan isolat 3/ASB 4.4.1 memperlihatkan adanya aktivitas penghambatan terhadap bakteri uji $S$. aureus dan E. coli. Sementara pada isolat 2/ASB 4.2.1 tidak menunjukkan adanya aktivitas penghambatan terhadap bakteri $S$. aureus maupun E. coli.

Adanya aktivitas antimikroba pada skrining dapat dihubungkan dengan bakteri yang bersimbion dengan ascidian tersebut. Beberapa penelitian menunjukkan bahwa bakteri yang bersimbion dengan ascidian memiliki pertahanan yang baik dalam melindungi diri di lingkungan tempat hidupnya. Sehingga memungkinkan bakteri yang bersimbion dengan ascidian $H$. momus menghasilkan senyawa antibakteri. Hal ini diduga bahwa di lingkungan tempat hidupnya ascidian memproduksi senyawa antimikroba dalam bentuk metabolit sekunder untuk melawan semua ancaman yang dihadapinya (Opa, dkk. 2018).

Senyawa antibakteri dapat digolongkan juga sebagai spektrum luas dan spektrum sempit. Spektrum luas artinya senyawa tersebut bekerja aktif terhadap banyak jenis bakteri baik bakteri gram positif dan bakteri gram negatif. Sedangkan spektrum sempit artinya suatu senyawa bekerja aktif hanya terhadap satu golongan bakteri saja baik hanya pada bakteri gram positif ataupun hanya pada bakteri gram negatif (WHO, 2014). Dari hasil penelitian ini menunjukkan bahwa senyawa antibakteri ascidian Herdmania momus termasuk berspektrum luas dikarenakan kemampuannya menghambat bakteri gram positif dan gram negatif.

\section{KESIMPULAN}

Berdasarkan hasil penelitian yang dilakukan, maka dapat disimpulkan bahwa:

1. Sebanyak total 62 isolat bakteri yang hidup bersimbion dengan ascidian Herdmania momus berhasil diisolasi, yakni 18 isolat dari ASB 4.4.2, 23 isolat dari ASB 4.2.1 dan 21 isolat dari ASB 4.4.1.

2. Skrining aktivitas antibakteri menunjukkan adanya penghambatan dari isolat bakteri simbion ASB 4.2.1, ASB 4.4.1 dan ASB 4.4.2 terhadap bakteri uji $S$. aureus dan $E$. coli

\section{DAFTAR PUSTAKA}

Gosliner, T. M., Behrens, D. W., Williams, G. C. 1996. Coral Reef Animals of the IndoPasific. Monterey, California. Hal: 299. 
Karim, F., Putra, Y.M., Hadi, A. T., Abrar, M. 2018. Antimicrobial and Cytotoxic Properties of the Ascidians Lissoclinum patella, Oxycoryna fascicularis, Didemnum molle and Botryllus schlosseri. Original article. Pharmaceutical Sciences and Research (PSR). 5 (2): 65-71.

Mangindaan, R.E.P., dan Taroreh., R.Y. 2013. Pengujian Aktivitas Larvasida dari Ekstrak Ascidian Lissoclinum pattela Terhadap Larva Nyamuk Aedes aegypti. Jurnal Pesisir dan Laut Tropis. 3(1):1317.

Opa, S. L., Bara, R. A., Gerung G. S., Rompas, R. M. Lintang, R. A. J., Sumilat, D. A. 2018. Uji Aktivitas Antibakteri Fraksi NHeksana, Metanol Dan Air Dari Ascidian Lissoclinum sp. Jurnal Pesisir dan Laut Tropis. 1 (1): 69-80.

Pastra, D. A., Melki dan Surbaktii A. 2012. Penapisan Bakteri yang Bersimbiosis dengan Spons Jenis Aplysina sp. Sebagai Penghasil Antibakteri dari Perairan Pulau Tegal Lampung. Jurnal Maspari 4 (1): 77-82.

Rumengan, A.P. 2010. Uji Larvasida Nyamuk (Aedes aegypti) dari Ascidian (Didemnum molle). Jurnal Perikanan dan Kelautan. 6 (2):83-86.

Sumilat, D.A., Wewengkang, D.S., Paruntu, C.P., Rotinsulu, H. 2017. Inhibitory
Activities of Ascidian Herdmania momus on the Colony Formation of Chinese Hamster V79 Cells, collected in Manado North Sulawesi, Indonesia. Jurnal of Asean Studies and Maritime Issues. 3 (5):13-19

Sumilat, D. A., Rimper J. R. T. S. L., Opa T. E., Kurnia D. 2019. The Potential of Marine Ascidians as Sources of Natural Antioxidant and Antibacterial agents from Manado, North Sulawesi. AACL Bioflux 12 (1): 373-377.

Tatsuta T., Hosono M., Rotinsulu H., Wewengkang D.SS., Sumilat D. A., Namikoshi M., Yamazaki H. 2017. Lissoclibadin 1, a polysulfur aromatic alkaloid from the Indonesian ascdian Lissoclinum cf. badium, induces capasedependent apoptosis in human colon cancer cells and suppresses tumor growth in nude mice. Journal of Natural Products 80 (2): 499-502.

Varghese, N., Joy, P. P. 2014. Microbiology Laboratory Manual. Pineapple Research Station. Kerala Agricultural University. Hal. 1-77.

Watters D. J., 2018 Ascidian toxin with potential for drug development. Marine Drugs 16 (5): 162.

WHO. 2014. Antmicrobial resistance: global report on survaillance 2014. World Health Organization. Hal. 257. 